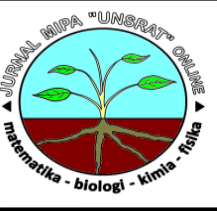

\title{
Analisis Air Limbah Pertambangan Emas Tanpa Izin Desa Bakan Kecamatan Lolayan Kabupaten Bolaang Mongondow
}

\author{
Puspita R. Gania*, Jemmy Abidjulua, Audy D. Wuntua \\ aJurusan Kimia, FMIPA, Unsrat, Manado
}

\begin{tabular}{l} 
K A T A K U N I \\
\hline Limbah \\
Pertambangan Emas Tanpa \\
Izin (PETI) \\
Kualitas Air
\end{tabular}

\begin{abstract}
A B S T R A K
Telah dilakukan penelitian untuk menganalisis kualitas air limbah yang berasal dari Pertambangan Emas Tanpa Izin (PETI) di Desa Bakan Kecamatan Lolayan Kabupaten Bolaang Mongondow. Parameter yang diukur adalah $\mathrm{pH}$, padatan tersuspensi total (TSS), tembaga, kadmium, zink, timbal, arsen, nikel, kromium, merkuri, dan sianida. Pengambilan sampel dilakukan pada empat lokasi di sepanjang aliran air limbah buangan dari lokasi pertambangan emas. Nilai hasil pengukuran selanjutnya dibandingkan dengan Keputusan Menteri Negara Lingkungan Hidup No. 202 Thn. 2004 tentang Baku Mutu Air Limbah Bagi Kegiatan Penambangan Bijih Emas/Tembaga dan Keputusan Menteri Negara Lingkungan Hidup Republik Indonesia Nomor 5 Thn. 2014 tentang Baku Mutu Air Limbah. Hasil penelitian menunjukkan bahwa nilai pH di satu lokasi pengambilan sampel dan nilai TSS di dua lokasi pengambilan sampel berada di luar nilai baku mutu yang telah ditetapkan, sedangkan konsentrasi sianida dan semua logam yang dianalisis masih berada di bawah ambang batas yang ditetapkan.
\end{abstract}

\begin{tabular}{l}
\hline KEY W O R D S \\
\hline Waste \\
$\begin{array}{l}\text { Unlicensed Gold Mining } \\
\text { (PETI) }\end{array}$
\end{tabular}

A B S T R A C T

A research aimed to analyze quality of wastewater from Unlicensed Gold Mine in Bakan Village Lolayan District Bolaang Mongondow Regency has been conducted. Parameters examined were $\mathrm{pH}$, total suspended solid (TSS), copper, cadmium, zinc, lead, arsenic, nickel, chromium, mercury, and cynide. Sampling was performed at four locations along the flow of wastewater sourced from unlicensed gold mine. The results were then compared to Decree of the Minister of State for the Environment No. 202 Yrs. 2004 on the Quality Standard of Waste Water from Gold/Copper Ore Mining Activities and Decree of the Minister of State for the Environment No. 5 Yrs. 2014 on the Quality Standard of Waste Water. The results showed that $\mathrm{pH}$ value at one location of sampling and TSS value at two locations of sampling were beyond the predefined quality standard, while the concentration of cyanide and all metals analyzed were below the prescribed threshold.

TERSEDIA ONLINE

1 Agustus 2017

\section{Pendahuluan}

Pertambangan emas tradisional merupakan salah satu kegiatan ekonomi masyarakat di mana para penambang memperoleh penghasilan yang cukup dari aktivitas tersebut. Proses pengolahan emas ini dilakukan dengan mengikuti beberapa tahapan antara lain penggalian batuan, pengolahan, dan pembuangan limbah (Sumual, 2009). Menurut Bapedalda Provinsi Sulawesi Utara (2002) pada tahun 2000 terdapat sekitar 22.000 orang, dibagi dalam dua kelompok yakni kegiatan pertambangan emas rakyat yang mempunyai izin (Wilayah Penambangan Rakyat) dan kegiatan pertambangan emas rakyat yang tidak mempunyai izin.

Berdasarkan penelitian yang pernah dilakukan oleh Abidjulu (2008), daerah pertambangan khususnya tambang emas menghasilkan limbahlimbah yang mengandung senyawa toksik (logam

*Corresponding author: Jurusan Kimia FMIPA UNSRAT, Jl. Kampus Unsrat, Manado, Indonesia 95115; Email address: ayuayuayugani@gmail.com Published by FMIPA UNSRAT (2017) 
berat). Sebagian sungai tersebut sudah menjadi tempat pembuangan limbah yang berasal dari berbagai kegiatan manusia seperti limbah rumah tangga. Limbah pembuangan yang dibuang berupa limbah organik maupun anorganik.

Di Sulawesi Utara terdapat dua aktivitas pertambangan yaitu pertambangan emas tradisional dan pertambangan modern yang dilakukan oleh masyarakat yang salah satunya berada di Kabupaten Bolaang Mongondow. Daerah pertambangan itu terletak di Kecamatan Lolayan yang berada di dua desa yaitu Desa Bakan dan Desa Tanoyan. Desa Bakan ini secara astronomis terletak pada koordinat 64500-61500 BT-643700645800 LS dengan luas daerah $6,3 \mathrm{~km}^{2}$, yang berada pada peta geologi lembar Kotamobagu skala $1: 50.000$ (Arifin, 2013).

Peneliti tertarik mengambil penelitian di Daerah Aliran Sungai Desa Bakan, karena terdapat pertambangan modern yaitu PT. J-Resource Bolaang Mongondow (JRBM) yang ikut beroperasi di sekitar gunung yang sama yaitu gunung Tapa'Gale dengan pertambangan tradisonal yang menjadi lokasi penelitian. Apabila terjadi hujan maka tempat pembuangan limbah dari perusahaan tersebut sering kali meluap ke beberapa tempat seperti sungai, sawah, dan pemukiman warga Desa Bakan. Terkadang warga mengeluh karena sering terjadi perubahan warna air aliran sungai di sekitar pemukiman. Berdasarkan informasi tersebut maka dilakukan analisis kualitas air di daerah aliran sungai Desa Bakan, di mana air sungai tersebut digunakan sebagai sumber air irigasi sawah, dan untuk kebutuhan rumah tangga sehari-hari. parameter yang dianalisis adalah $\mathrm{pH}$, padatan tersuspensi total TSS, tembaga $(\mathrm{Cu})$, kadmium $(\mathrm{Cd})$, seng $(\mathrm{Zn})$, timbal $(\mathrm{Pb})$, arsen (As), nikel (Ni), kromium (Cr), merkuri (Hg) yang mengacu pada Keputusan Menteri Negara Lingkungan Hidup No. 202 Thn. 2004 tentang Baku Mutu Air Limbah Bagi Kegiatan Penambangan Bijih Emas/Tembaga. Disamping itu peneliti juga menganalisis sianida karena pada pertambangan ini tidak menggunakan proses amalgamasi yang menggunakan merkuri (Hg), tetapi yang digunakan

Tabel 1. Hasil Analisa Tiap Parameter adalah proses sianidasi yang menggunakan sianida yang mengacu pada Keputusan Menteri Negara Lingkungan Hidup Republik Indonesia Nomor 5 Thn. 2014 tentang Baku Mutu Air Limbah.

\section{Metode \\ Alat dan Bahan}

Alat utama yang digunakan dalam penelitian ini Atomic Absorption Spectrophotometer (AAS) (AA7000 Shimadzu), dan Spectrophotometer SpectroDirect Lovibond dengan perlengkapannya.

Bahan-bahan yang digunakan adalah air buangan limbah, $\mathrm{HNO}_{3}$, dan larutan induk logamlogam $\mathrm{Cu}, \mathrm{Cd}, \mathrm{Zn}, \mathrm{Pb}, \mathrm{As}, \mathrm{Ni}, \mathrm{Cr}$, dan $\mathrm{Hg}$

\section{Teknik Pengambilan Sampel}

Sampel air limbah dari empat titik pengambilan sampel ditampung dalam 4 botol polietilen masingmasing dengan volume $2 \mathrm{~L}$ dan disimpan dalam kulkas dengan suhu $4{ }^{\circ} \mathrm{C}$. Titik pertama (T1) terletak pada jarak $25 \mathrm{~m}$ sesudah pembuangan limbah, titik kedua (T2) terletak pada jarak $70 \mathrm{~m}$ dari titik T1, titik ke tiga (T3) terletak pada jarak 100 m dari titik T2, dan titik keempat (T4) terletak pada jarak 150 m dari titik T3.

\section{Prosedur}

Pengukuran $\mathrm{pH}$ air limbah dilakukan menggunakan pH meter mengikuti SNI 06-6989.112004, penentuan TSS dilakukan dengan metode gravimeteri mengikuti SNI 06-6989.11-2004, penentuan kadar logam dilakukan dengan menggunakan spektrofotomer serapan atom Shimadzu AA-7000 mengikuti SNI 6989.18-2009 dan SNI 01-3554-2006, dan penentuan sianida dilakukan menggunakan spektrofotometer SpectroDirect Lovibond mengikuti SNI 6989.772011.

\section{Hasil dan Pembahasan}

Hasil pengukuran untuk parameter-parameter $\mathrm{pH}$, TSS, sianida, dan logam-logam tembaga, kadmium seng, timbal, arsen, nikel, kromium, dan merkuri ditunjukkan pada Tabel 1.

\begin{tabular}{|c|c|c|c|c|c|c|}
\hline \multirow{2}{*}{ No } & \multirow{2}{*}{ Parameter } & \multicolumn{4}{|c|}{ Hasil Analisa } & \multirow{2}{*}{$\mathrm{BM}$} \\
\hline & & T1 & T2 & T3 & T4 & \\
\hline 1 & $\mathrm{pH}$ & 6,85 & 7,02 & 5,71 & 6,57 & $6-9$ \\
\hline 2 & TSS & 970 & 3650 & 10 & 10 & 200 \\
\hline 3 & Tembaga (Cu) & $<0,0012$ & $<0,0012$ & $<0,0012$ & $<0,0012$ & 2 \\
\hline 4 & Kadmium (Cd) & 0,0015 & 0,0014 & 0,0021 & 0,0014 & 0,1 \\
\hline 5 & Seng (Zn) & 0,02 & 0,03 & 0,10 & 0,05 & 5 \\
\hline 6 & Timbal (Pb) & 0,011 & 0,007 & 0,005 & 0,006 & 1 \\
\hline 7 & Arsen (As) & 0,001 & 0,0013 & 0,002 & 0,0015 & 0,5 \\
\hline 8 & Nikel (Ni) & $<\mathrm{LD}$ & 0,03 & 0,03 & 0,05 & 0,5 \\
\hline 9 & Kromium (Cr) & 0,005 & 0,001 & 0,0007 & 0,0006 & 1 \\
\hline 10 & Raksa (Hg) & $<0,0006 \times 10^{-3}$ & $<0,0006 \times 10^{-3}$ & $<0,0006 \times 10^{-3}$ & $<0,0006 \times 10^{-3}$ & 0,005 \\
\hline 11 & Sianida $(C n)$ & 0,00 & 0,00 & 0,00 & 0,00 & 0,2 \\
\hline
\end{tabular}

Dari hasil penelitian yang telah dilakukan telah diperoleh tingkat derajat keasaman yang berbeda- beda dari titik pengambilan sampel menunjukkan kenaikan dan terjadi fluktuasi dari T1 sampai T3 
dengan nilai T1 6,85; T2 7,02; dan T3 5,71. T3 merupakan satu titik yang tidak memenuhi syarat baku mutu dengan nilai pH dibawah 6 yaitu 5,71. T3 terletak di pertengahan jembatan dan sawah, hal ini juga disebabkan titik temu 2 limbah pertambangan yaitu limbah pertambangan emas tanpa izin (PETI) secara tradisional dan modern (PT. J-Resource Bolaang Mongondow). Limbah tersebut mengandung senyawa organik yang dapat menurunkan nilai $\mathrm{pH}$ sehingga air sungai akan bersifat asam.

Dengan hasil yang diperoleh pada pengujian TSS, dari T1 sebesar $970 \mathrm{mg} / \mathrm{l}$ dan pada T2 memiliki nilai yang paling tinggi dibandingkan dengan 4 titik pengambilan sampel lainnya yaitu sebesar 3650 mg/l. Nilai T1 dan T2 mempunyai nilai yang tinggi pada parameter total padatan tersuspensi dikarenakan pada T1 merupakan titik yang masih berada di lokasi Pertambangan Emas Tanpa Izin (PETI) dan T2 merupakan titik yang berada didepan jalan yang digunakan masyarakat sebagai lalu lintas para penambang. Kedua titik yang mempunyai nilai total padatan tersuspensi yang tinggi ini mempunyai efek yang kurang baik terhadap kualitas badan air karena dapat menyebabkan menurunkan kejernihan air dan dapat mempengaruhi kemampuan ikan untuk melihat dan menangkap makanan serta menghalangi sinar matahari masuk ke dalam air. Menurut Nofitasari (2012), kandungan total padatan tersuspensi dalam badan air sering menunjukan konsentrasi yang lebih tinggi pada bakteri, nutrien, pestisida, dan logam didalam air sehingga akan mempengaruhi regenerasi oksigen serta fotosintesis. Sedangkan pada T2 ke T3 dan T4 mengalami penurunan dan kedua titik tersebut memiliki nilai yang sama yaitu $10 \mathrm{mg} / \mathrm{l}$, untuk nilai kedua titik tersebut masih berada pada standar baku mutu yang berdasarkan pada Keputusan Menteri Negara Lingkungan Hidup No. 202 Thn. 2004 tentang Baku Mutu Air Limbah Bagi Kegiatan Penambangan Bijih Emas/Tembaga. Menurut Nugeraha (2010), proses penurunan TSS dapat dipahami karena TSS adalah polutan yang berada dalam bentuk tersuspensi sehingga banyaknya flok yang terbentuk dan akhirnya terjadi pengendapan, hal ini menyebabkan TSS menurun.

Pada pengujian logam tembaga (Cu) Spektrofotometer Serapan Atom (AA-7000 Shimadzu) pada pembacaan pada T1, T2, T3, dan T4 mencapai Limited Detection (LD) yaitu dengan nilai $<0,0012 \mathrm{mg} /$. kemungkinan logam tembaga (Cu) nilainya terbilang dibawah nilai Limited Detection (LD) pada alat Spektrofotometer Serapan Atom (AA-7000 Shimadzu) sehingga tidak dapat di cantumkan oleh alat nilai pada logam tembaga $(\mathrm{Cu})$ yang dikandung. Kadar tembaga (Cu) ini lebih rendah dari kadar normal nilai Baku Mutu Air Limbah bagi Kegiatan Penambangan Bijih Emas dan atau Tembaga No: 202 Tahun 2004 yaitu berkisar 2 $\mathrm{mg} / \mathrm{l}$, maka kadar tembaga (Cu) hasil pengamatan ini belum berbahaya bagi kehidupan biota perairan.
Menurut Tarigan (2003), tembaga (Cu) termasuk dalam logam esensial, dan dalam kadar yang rendah dibutuhkan oleh organisme sebagai koenzim dalam proses metabolisme tubuh dan sifat racunnya baru muncul dalam kadar yang tinggi. Dari Tabel 1 dapat dilihat kadar kadmium (Cd) juga memiliki nilai yang baik yaitu dengan perolehan nilai dari $\quad \mathrm{T} 1=0,0015 ; \quad \mathrm{T} 2=0,0014 ; \quad \mathrm{T} 3=0,0021$; $\mathrm{T} 4=0,0014$ dan tidak melampaui batas nilai baku mutu yang telah ditetapkan Baku Mutu Air Limbah bagi Kegiatan Penambangan Bijih Emas dan atau Tembaga No: 202 Tahun 2004 yaitu dengan nilai $0,1 \mathrm{mg} / \mathrm{l}$. Pada titik T2 dan T4 memiliki nilai yang sama, kadar keempat titik ini belum berbahaya bagi kehidupan biota perairan.

Seng (Zn) dalam air berasal dari limbah industri pertambangan. Logam ini penting dalam penyusunan logam enzim dan beracun bagi tanaman pada konsentrasi yang cukup tinggi (Adinata, 2015). Berdasarkan penelitian yang telah dilakukan kadar seng (Zn) pada limbah Pertambangan Emas Tanpa Izin Desa Bakan yaitu berkisar $\mathrm{T} 1=0,02 ; \mathrm{T} 2=0,03 ; \mathrm{T} 3=0,10$; dan $\mathrm{T} 4=0,05$. Keempat titik tersebut belum mencemari DAS Desa Bakan karena tidak melebihi nilai Baku Mutu Kegiatan Penambangan Bijih Emas dan atau Tembaga No: 202 Tahun 2004 yaitu dengan nilai 5 $\mathrm{mg} / \mathrm{l}$. Tetapi pada baku mutu air kelas dua menurut PP No.82 tahun 2001 pada T3=0,10 dan T4=0,05 sudah melewati batas baku mutu yang ditetapkan oleh PP No.82 tahun 2001 yaitu dengan nilai 0,05. Karena sebagian besar aktivitas penduduknya banyak memanfaatkan air sungai seperti mandi, dan mencuci pakaian. Beberapa sabun dan detergen mengandung unsur seng $(\mathrm{Zn})$ dan bahanbahan keperluan rumah tangga berupa cat rumah sehingga meningkatkan konsentrasi seng (Zn) yang melewati syarat kriteria baku mutu air kelas II PP No.82 tahun 2001 (Abidjulu, 2008). Kadar timbal $(\mathrm{Pb})$ pada penelitian yang telah dilakukan menunjukkan bahwa air limbah Pertambangan Emas Tanpa Izin (PETI) Desa Bakan mengandung logam timbal $(\mathrm{Pb})$ keempat titik yang telah diuji. $\mathrm{T} 1=0,011 ; \mathrm{T} 2=0,007 ; \mathrm{T} 3=0,005 ;$ dan $\mathrm{T} 4=0,006$ keempat titik tersebut mengandung kadar logam timbal yang sedikit, sehingga nilai kadar timbal $(\mathrm{Pb})$ tersebut belum mencemari dan melewati nilai Baku Mutu Kegiatan Penambangan Bijih Emas dan atau Tembaga No: 202 Tahun 2004 yaitu dengan nilai 1 $\mathrm{mg} / \mathrm{l}$. Jika kadar timbal $(\mathrm{Pb})$ tinngi, logam ini dapat bersifat racun dan mengakibatkan anemia, sakit ginjal, kerusakan sistem saraf serta merusak kehidupan binatang. Logam ini berada dalam darah dapat bereaksi dengan reaktif terhadap oksigen dan membentuk senyawa $\mathrm{PbO}$ yang sangat tidak dibutuhkan oleh hemoglobin darah (Zubayr, 2009).

Berdasarkan Tabel 1 hasil analisa tiap parameter yang diuji kadar arsen (As) tiap titik adalah T1=0,001; T2=0,0013; T3=0,002; dan $\mathrm{T} 4=0,015$. Keempat titik tersebut belum melewati batas nilai standar baku mutu pada Keputusan Menteri Negara Lingkungan Hidup No. 202 Thn. 
2004 tentang Baku Mutu Air Limbah Bagi Kegiatan Penambangan Bijih Emas/Tembaga yaitu sebesar $0,5 \mathrm{mg} / \mathrm{l}$. Keberadaan arsen (As) dialam yaitu dibatuan atau tanah, arsen (As) terdistribusi sebagai mineral. Kadar arsen (As) tertinggi dalam bentuk arsenida dari amalgam tembaga, timah hitam, perak dan bentuk sulfida dari emas. Arsen terlarut dalam air dalam bentuk organik dan anorganik adalah methylarsenic acid, sedangkan anorganik dalam bentuk arsenit dan arsenat. Arsen (As) dapat ditemukan pada permukaan air, air sungai, air danau, air sumur dalam, air mengalir, serta pada air dilokasi dimana terdapat aktivitas panas bumi.

Kadar nikel (Ni) pada kerak bumi sekitar 75 $\mathrm{mg} / \mathrm{kg}$. Sumber utama nikel (Ni) berasal dari pengikisan batuan yang bersifat nonkonservatif pada perairan dan ditemukan dalam bentuk koloid (Moore, 1991). Berdasarkan hasil yang diperoleh, konsentrasi logam nikel ( $\mathrm{Ni}$ ) yang diuji dengan alat Atomic Absorption Spectrophotometer (AA-7000 Shimadzu) pada empat titik di perairan sungai Desa Bakan Kecamatan Lolayan Kabupaten Bolaang Mongondow yang di aliri limbah pembuangan cair Pertambangan Emas Tanpa Izin (PETI) menunjukan sedikit kenaikan dari T1 ke T4 dengan nilai T1:0, T2:0,03, T3: 0,03, dan T4:0,05. Tetapi dengan nilai yang diperoleh dari ke 4 titik tersebut masih stabil dan belum mencemari perairan tersebut sesuai dengan standar baku mutu pada Keputusan Menteri Negara Lingkungan Hidup No. 202 Thn. 2004 tentang Baku Mutu Air Limbah Bagi Kegiatan Penambangan Bijih Emas/Tembaga yaitu sebesar $0,5 \mathrm{mg} / \mathrm{l}$. Peningkatan kadar Ni yang terjadi pada T1 sampai T2 karena konsentrasi nikel terlarut pada tingkat kekeruhan yang tinggi terjadi karena proses desorpsi, dari partikel-partikel yang ada disungai dan proses resuspensi (Zubayr, 2009). Kromium (Cr) termasuk unsur yang jarang ditemukan pada perairan alami. Kadar kromium (Cr) pada kerak bumi mengandung sekitar 100 mg/l (Moore, 1991). Berdasarkan hasil yang diperoleh, konsentrasi logam kromium $(\mathrm{Cr})$ yang diuji dengan alat Atomic Absorption Spectrophotometer (AA-7000 Shimadzu) pada empat titik di perairan sungai Desa Bakan Kecamatan Lolayan Kabupaten Bolaang Mongondow yang di aliri limbah pembuangan cair Pertambangan Emas Tanpa Izin (PETI) terjadi fluktuasi dari T1 sampai T4. Dengan nilai yang diperoleh pada T1 sebesar 0,005, T2 0,001, T3 0,0007 , dan T4 sebesar 0,0006. Tetapi dengan nilai yang diperoleh dari ke 4 titik tersebut masih stabil dan belum mencemari perairan tersebut sesuai dengan standar baku mutu pada Keputusan Menteri Negara Lingkungan Hidup No. 202 Thn. 2004 tentang Baku Mutu Air Limbah Bagi Kegiatan Penambangan Bijih Emas/Tembaga yaitu sebesar 1 mg/l. Kadar kromium (Cr) pada perairan air tawar biasanya kurang dari 0,001 mg/l. Kadar Kromium yang diperkirakan aman bagi kehidupan akuatik adalah sekitar 0,05 mg/l. Sumber-sumber masukan logam kromium $(\mathrm{Cr})$ pada perairan di duga paling banyak adalah dari kegiatan perindustrian, kegiatan rumah tangga, dan dari pembakaran serta mobilisasi bahan-bahan bakar (Palar, 1994).

Pada pengujian merkuri (Hg), memperoleh kadar logam merkuri $(\mathrm{Hg})$ yang telah melewati nilai Limited Detection (LD) pada pembacaan alat Atomic Absorption Spectrophotometer (AAS) (AA-7000 Shimadzu) dengan nilai < 0,0006 x 10-3 tiap titik (T1, T2, T3, dan T4). Sehingga kadar merkuri yang diperoleh tidak melebihi nilai pada Keputusan Menteri Negara Lingkungan Hidup No. 202 Thn. 2004 tentang Baku Mutu Air Limbah Bagi Kegiatan Penambangan Bijih Emas/Tembaga yaitu sebesar 0,005 mg/l. Hal ini dikarenakan pada pertambangan ini tidak menggunakan merkuri $(\mathrm{Hg})$ pada proses amalgamasi, tetapi yang digunakan adalah sianida (CN), proses sianidasi pada Pertambangan Emas Tanpa Izin (PETI) Desa Bakan. Peneliti menguji logam merkuri (Hg) dikarenakan logam tersebut terdapat salah satu parameter yang harus diuji di Keputusan Menteri Negara Lingkungan Hidup No. 202 Thn. 2004 tentang Baku Mutu Air Limbah Bagi Kegiatan Penambangan Bijih Emas/Tembaga. Merkuri merupakan zat yang sangat beracun bagi makhluk hidup baik sebagai unsur tunggal maupun yang telah membentuk persenyawaan (Palar, 1994). Beberapa sumber polutan yang menyebabkan terjadinya penimbunan merkuri di DAS, yang terpenting adalah industri penambangan logam, industri bijih besi, termasuk metal plating, industri yang memproduksi bahan kimia, baik organik maupun anorganik, dan sampah domestik (offshore dumping), lumpur dan lain-lain. Proses amalgamasi menyebabkan besarnya merkuri yang hilang ke lingkungan, sehingga besar pula resiko bahaya kesehatan yang dihadapi, terutama yang melakukan pengolahan bijih emas yang berinteraksi langsung dengan merkuri tersebut akan mudah terkontaminasi merkuri yaitu melalui udara yang dihirupnya yang telah terkontaminasi merkuri (Siallagan, 2010).

Berdasarkan hasil yang diperoleh, konsentrasi logam sianida (CN) yang diuji dengan alat Spectrophotometer SpectroDirect Lovibond pada empat titik di perairan sungai Desa Bakan Kecamatan Lolayan Kabupaten Bolaang Mongondow yang di aliri limbah pembuangan cair Pertambangan Emas Tanpa Izin (PETI) tidak mempunyai kandungan pada empat titik tersebut. T1-T4 pembacaan nilainya adalah $0 \mathrm{mg} / \mathrm{l}$, dengan nilai yang diperoleh dari ke 4 titik tersebut masih stabil dan belum mencemari perairan tersebut sesuai dengan standar baku mutu pada Keputusan Menteri Negara Lingkungan Hidup Republik Indonesia Nomor 5 Thn. 2014 tentang Baku Mutu Air Limbah yaitu sebesar $0,2 \mathrm{mg} / \mathrm{l}$.

Hal ini di karenakan limbah sianida yang telah digunakan pada proses sianidasi/ ekstraksi emas tidak di buang langsung pada perairan tetapi limbah sinida yang telah digunakan dipakai kembali untuk sianidasi agar menghemat biaya dan mencegah tercemarnya sianida (CN) oleh penambang. Mungkin juga kadar sianida (CN) yang terlalu kecil nilainya 
sehingga sulit untuk dibaca pada alat Spectrophotometer SpectroDirect Lovibond. Tetapi jika terjadi hujan, tanah yang dipakai pada proses sianidasi sering meluap ke perairan, sehingga di mungkinkan perairan Desa Bakan akan mengandung sianida (CN). Pada perairan Desa Bakan mungkin tidak mengandung logam sianida $(\mathrm{CN})$, tetapi belum tentu pada udara disekitar pertambangan tidak terdapat sianida (CN) yang menguap dalam bentuk gas, apalagi para penambang tidak menggunakan alat safety yang umumnya diharuskan penambang menggunakannya. Siallagan (2010) juga menyebutkan bahwa pemakaian garam-garam sianida pada industri, seperti pengolahan emas dapat menimbulkan dampak negatif terhadap kesehatan penambang. Persenyawaan sianida yang berupa gas sangat mudah diserap oleh paru-paru dan penyerapan melalui kulit umumnya lambat. Serangan sianida berjalan cepat, gejala yang timbul umumnya: lemah, sakit kepala, pandangan kabur, dan kadang-kadang pingsan.

\section{Kesimpulan}

Dari hasil dan pembahasan dapat disimpulkan sebagai berikut ini:

Berdasarkan hasil penelitian yang telah dilakukan, bahwa kualitas perairan Desa Bakan Kecamatan Lolayan Kabupaten Bolaang Mongondow telah mengalami penurunan kualitas air bagi pemanfaatannya oleh warga setempat. Penurunan kualitas ini dilihat dari beberapa pengujian parameter yang menunjukan kadar $\mathrm{pH}$ (derajat keasaman), dan total padatan tersuspensi (TSS) yang memiliki nilai yang melampaui baku mutu yang ditetapkan sesuai pada Keputusan Menteri Negara Lingkungan Hidup No. 202 Thn. 2004 tentang Baku Mutu Air Limbah Bagi Kegiatan Penambangan Bijih Emas/Tembaga, dengan nilai masing-masing 5,71, $970 \mathrm{mg} / \mathrm{l}$, dan 3650 $\mathrm{mg} / \mathrm{l}$.

\section{Daftar Pustaka}

Abidjulu, J. 2008. Analisis Kualitas Air Sungai Tanoyan di Kota Kotamobagu Provinsi Sulawesi Utara. Chemistry Progress. 1(2): 105-110.

Adinata, D. Y. 2015. Identifikasi Limbah Pengolahan Emas dan Kualitas Air di Sekitar Penambangan Emas Rakyat Jampang Kulon, Desa Kertajaya, Kab. Sukabumi, Jawa Barat. Prosiding Seminar Nasional Sains dan Teknologi Terapan III.

Agus, C. 2005. Dampak Limbah Cair Hasil Pengolahan Emas Terhadap Kualitas Air Sungai dan Cara Mengurangi Dampak dengan Menggunakan Zeolit. Jurnal Manusia dan Lingkungan. 12(1): 13-19

Arifin, A. 2013. Tipe Endapan Epitermal Daerah Prospek Bakan Kecamatan Lolayan Kabupaten Bolaang Mongondow Propinsi Sulawesi Utara. Jurnal IImiah MTG. 6(1): 361-370.

Badan Stadardisasi Nasional. 2004. SNI 066989.11-2004. Air dan Air Limbah - Bagian 11:
Cara Uji Derajat Keasaman $(\mathrm{pH})$ dengan

Menggunakan Alat pH Meter.

Badan Stadardisasi Nasional. 2004. SNI 06-6989.32004. Air dan Air Limbah - Bagian 3 : Cara Uji Padatan Tersuspensi Total (Total Suspended Solid, TSS) Secara Gravimetri.

Badan Stadardisasi Nasional. 2006. SNI 01-35542006. Air dan Air Limbah - Bagian 17 : Cara Uji Logam Krom ( $\mathrm{Cr})$ dengan Metode Spektrofotometer Serapan Atom (SSA) - Nyala.

Badan Stadardisasi Nasional. 2009. SNI 6989-182009. Air dan Air Limbah - Bagian 6 : Cara Uji Nikel (Ni) dengan Metode Spektrofotometer Serapan Atom (SSA) - Nyala.

Badan Stadardisasi Nasional. 2011. SNI 6989.772011. Air dan Air Limbah - Bagian 7 : Cara Uji Sianida (Cn).

Bapedalda Sulut. 2002. Penelitian Tentang Limbah Merkuri di Propinsi Sulawesi Utara Selang 2001 sampai 2002, Sub Bidang Pengendalian Pencemar Air. Bapedalda. Manado.

Effendi, H. 2003. Telaah Kualitas Air Bagi Pengelolaan Sumberdaya Perairan. Kanisius. Yogyakarta.

Kitong, M. 2012. Analisis Merkuri (Hg) dan Arsen (As) di Sedimen Sungai Ranoyapo Kecamatan Amurang Sulawesi Utara. Jurnal Mipa Unsrat Online. 1(1): 16-19.

Listiana, V. 2013. Analisis Kadar Logam Berat Kromium (Cr) Dengan Ekstraksi Pelarut Asam Sulfat (H2SO4) Menggunakan Atomic Absorption Spectrofotometry (AAS) Di Sungai Donan (Cilacap) Pada Jarak $2 \mathrm{Km}$ Sesudah Pt. Pertamina [Skripsi]. IImu Pendidikan Kimia. FIT Keguruan. Semarang.

Lovibond. 2017. The Tintometer Limited, Lovibond House, Sun Rise Way, Amesbury, SP4 7GR. England.

Menteri Negara Lingkungan Hidup. 2004. Keputusan Menteri Negara Lingkungan Hidup Nomor Kep- 202/MenLH/II/2004 tentang baku mutu air limbah bagi Usaha dan atau Kegiatan Pertambangan Bijih Emas dan atau Tembaga. Jakarta.

Menteri Negara Lingkungan Hidup. 2014. Keputusan Menteri Negara Lingkungan Hidup Nomor Kep- 1815/MenLH/V/2014 tentang Baku Mutu Air Limbah. Republik Indonesia.

Mokobombang, M. E. 2016. Analisis Neraca Air Sungai Kinali di Titik Bendung Kinali Ongkag Kab. BOLMONG. Jurnal Sipil Statik. 4(12): 761770.

Mondoringin, W. J. 2007. Analisis Kadar Merkuri (Hg) dan Arsen (As) pada beberapa Sumber Air Sumur Gali Di Desa Buyat Kab. BOLMONG [Skripsi]. FMIPA UNSRAT. Manado.

Moore, J. W. 1991. Inorganic Contaminats of Surface Water. Springer-Verlag. New York.

Mundeng, F. 2014. Studi Analisis Tingkat Pencemaran Kadar Merkuri (Hg) Di Hulu Dengan Di Hilir Sungai Ongkag Mongondow 
Kabupaten Bolaang Mongondow [Skripsi]. FIIK UNG. Gorontalo.

Nofitasari, R. 2012. Studi Penurunan Konsentrasi Nikel dan Tembaga pada Limbah Cair Elektroplating dengan Metode Elektrokoagulasi. Jurnal Pendidikan Indonesia. 20(3): 130-149.

Nugeraha. 2010. Pengolahan Air Limbah Kegiatan Penambangan Batubara Menggunakan Biokoagulan: Studi Penurunan Kadar TSS, Totalfe dan Total Mn Menggunakan Biji Kelor (Moringa Oleifera). Jurnal Presitipasi. 7(2): 1907-187.

Palar, H. 1994. Pencemaran dan Toksikologi Logam Berta. Rineka Cipta. Jakarta.

Pitoi, M. M. 2015. Sianida: Klasifikasi, Toksisitas, Degradasi, Analisis. Jurnal MIPA UNSRAT. 4(1): 1-4.

Sepriani. 2016. Pengaruh Limbah Cair Industri Tahu Terhadap Kualitas Air Sungai Paal 4 Kecamatan Tikala Kota Manado [Skripsi]. FMIPA UNSRAT. Manado.
Siallagan, M. B. 2010. Analisis Buangan Berbahaya Pertambangan Emas di Gunung Pongkor [Skripsi]. IPB. Bogor.

Smith, A. and Mudder, T. 1991. The Chemistry and Treatment of Cyanidation Wastes. Mining Journal Books Ltd., London.

Sujiono, E. H. 2014. Karakteristik Sifat Fisis Batuan Nikel Di Sorowako Sulawesi Selatan. Jurnal Pendidikan Fisika Indonesia. 10(2): 163-167.

Sumual, H. 2009. Karakterisasi Limbah Tambang Emas Rakyat Dimembe Kabupaten Minahasa Utara. Jurnal Agritek. 17(5): 258-270.

Tarigan, Z. 2003. Kandungan Logam Berat Pb, Cd, $\mathrm{Cu}, \mathrm{Zn}$, dan Ni dalam Air Laut dan Sedimen di Muara Sungai Membramo, Papua dalam Kaitannya dengan Kepentingan Budidaya Perikanan. Jurnal Makara Sains. 7(3): 119-127.

Zubayr, S. A. 2009. Analisis Status Pencemaran Logam Berat di Wilayah Pesisir: Studi Kasus Pembuangan Limbah Cair dan Tailing Padat/Slag Pertambangan Nikel Pomalaa [Skripsi]. SPSAL IPB. Bogor. 